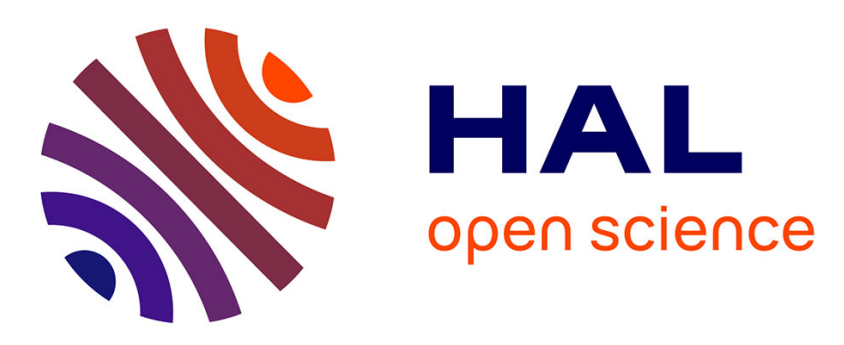

\title{
Dealing with power games in a companion modelling process : lessons from community water management in Thailand highlands
}

Cécile Barnaud, Annemarie van Paassen, Guy Trebuil, Tanya Promburom, François Bousquet

\section{To cite this version:}

Cécile Barnaud, Annemarie van Paassen, Guy Trebuil, Tanya Promburom, François Bousquet. Dealing with power games in a companion modelling process: lessons from community water management in Thailand highlands. The Journal of Agricultural Education and Extension, 2010, 16 (1), pp.55-74. hal-00609678

\section{HAL Id: hal-00609678 https://hal.science/hal-00609678}

Submitted on 19 Jul 2011

HAL is a multi-disciplinary open access archive for the deposit and dissemination of scientific research documents, whether they are published or not. The documents may come from teaching and research institutions in France or abroad, or from public or private research centers.
L'archive ouverte pluridisciplinaire HAL, est destinée au dépôt et à la diffusion de documents scientifiques de niveau recherche, publiés ou non, émanant des établissements d'enseignement et de recherche français ou étrangers, des laboratoires publics ou privés. 


\title{
Dealing with power games in a companion modelling process: lessons from community water management in Thailand highlands
}

Cécile Barnaud ${ }^{1,3}$, Annemarie Van Paassen², Guy Trébuil ${ }^{3}$, Tanya Promburom ${ }^{4}$, François Bousquet ${ }^{3}$

The final version of this article has been published in The Journal of Agricultural Education and Extension.

Barnaud C., Van Paassen A., Trébuil G., Promburom T., Bousquet F. (2010). Dealing with power games in a companion modelling process: lessons from community water management in Thailand highlands. Journal of Agricultural and Extension Education, 2010, 16 (1): 55-74.

\begin{abstract}
Although stakeholder participation is expected to promote equitable and sustainable natural resource management, lessons from the past tell us that more careful attention needs to be paid to achieving equitable impacts. Now the question is how to address social inequities and power asymmetries. Some authors emphasize the need for more dialogue, while others prefer a critical perspective, arguing that dialogue might not be sufficient to avert the risk of a process deepening existing social inequities. This article aims to enrich this debate and question the practical implications of the critical perspective through an in-depth analysis of power games in a participatory process.
\end{abstract}

A Companion Modelling (ComMod) process was conducted in an Akha community of Northern Thailand with a critical perspective, i.e. with a concern for the less influent stakeholders. Simulation tools such as role-playing games were used to mediate a crosscultural learning process among researchers, farmers and administrators about a local irrigation water management problem.

The detailed analysis of power games in this learning and negotiation process reveals that in spite of initial power asymmetries, the poorest farmers of the community started to voice and assert their interests.

\footnotetext{
${ }^{1}$ GECKO Laboratory, Department of Geography, Paris X University, Nanterre, 92000 France.

${ }^{2}$ Communication and Innovation Studies (CIS), Wagening University, Netherlands.

${ }^{3}$ CIRAD, UPR GREEN, Montpellier, F-34398 France \& CU-CIRAD ComMod project, Bangkok, 10330 Thailand.

${ }^{4}$ Multiple Cropping Center, Faculty of agriculture, Chiang Mai University, Thailand.
} 
We identify a set of practical facilitation methods that helped to manage power asymmetries and to level the playing field but we also discuss the main limits of our cultural-embedded methodological choices.

Acknowledging that 'the facilitators' neutrality' is an illusion, this study allows us to raise the question of their social legitimacy. We suggest that they should systematically make explicit their cultural-ideological background and methodological hypothesis and choices and their effects on the socio-political context. This article is an original attempt to accept this challenge.

\section{Key words}

Participatory approach, social inequities, power relations, cultural differences, critical system perspective, creative learning, negotiation, companion modelling, water management, northern Thailand

\section{Introduction}

As in other Southeast Asian countries, Thailand's recent policy-making framework regarding natural resource management favours decentralization and public participation (Arghiros, 2001). This is an important opportunity for ethnic minorities living in the highlands of northern Thailand who have been accused for many years by the Thai majority of degrading the upper watersheds of the country's major basins and had so far limited voice in decisionmaking processes affecting them (Mac Kinnon and Vienne, 1989).

However, stakeholder participation is challenging. Socio-ecosystems are complex and uncertain, with numerous interacting ecological and socio-economic dynamics, and an increasing number of stakeholders with different legitimate perspectives. There is a need for innovative methodologies and tools to enable stakeholders to manage such complex systems. The companion modelling (ComMod) approach accepts the challenge and proposes to coconstruct simulation tools integrating the different stakeholders' perspectives and to use them to enhance dialogue, collective learning and the exploration of possible scenarios in these complex socio-ecosystems (Barreteau et al., 2003; Bousquet et al., 1999).

But ComMod, like many other participatory approaches, is confronted with the issue of power inequalities. How to deal with local power differences? More and more authors argue that participatory interventions with little attention for the socio-political context tend to hurt the interests of less powerful stakeholders (Nelson and Wright, 1995; Wollenberg et al., 2001). 
Two main postures can be distinguished: those who believe in 'dialogue' and those who promote a 'critical perspective' (Faysse, 2006). Proponents of dialogue consider the lack of genuine communication as the main obstacle to fruitful collaboration and coordination. According to them, once this barrier is removed, it is possible to build a common vision through social learning and to achieve a consensus for collective action (Pretty, 1995; Röling and Wagemakers, 1998). But the promoters of the critical perspective argue that power relations need to be examined prior to the participatory process; otherwise, there is a high risk of the process deepening existing social inequities. These authors consider participation as a negotiation process rather than a social learning process (Edmunds and Wollenberg, 2001; Leeuwis, 2000). However, the "dialogue” and “critical” perspectives are not necessarily antagonist. Social learning is indeed the basis for creative and integrative negotiation processes (Leeuwis, 2004).

This article aims to enrich the debate about the way to deal with power inequities in participatory processes through an in-depth analysis of power dynamics in a ComMod experiment that adopted a critical posture. This ComMod experiment aimed to facilitate learning and negotiation about an irrigation water sharing problem in an Akha community in the highlands of northern Thailand. Given the importance of cultural differences among the participants in this cultural context, this paper emphasizes the role of cultural differences in power games in mediated cross-cultural learning processes.

This article starts with a presentation of the fundamental principles of the ComMod approach, our conceptual framework based on critical systems thinking and the ComMod methodology implemented at this site. A second section describes the initial socio-political and cultural context and analyses the expression and evolution of power games in the facilitated learning and negotiation process. The article ends with a discussion on the potential, limits and perspectives for the improvement of the ComMod approach to level the playing field and give voice to the perspective of the marginalized. Following Webler's (1999) advice, we not only focus on what works, but also analyse why it works and how it could work better. 


\section{Conceptual framework and research methodology}

\section{Fundamental principles of the ComMod approach}

ComMod is a participatory action research approach developed since the mid 1990's by a group $^{5}$ a researchers that use simulation tools to deal with complex systems in the field of management of renewable resources and the environment (Barreteau et al., 2003; Bousquet et al., 1999). ComMod researchers focus on the complexity and uncertainty of their research objects, and on the existence of multiple, legitimate perspectives, including those produced by scientific expertise. ComMod aims to integrate these different perspectives in an iterative process of understanding, confrontation and analysis. It can have two possible aims: to learn about systems or to support concerted processes in these systems. The ComMod approach applies a cyclical approach, alternating modelling and field activities, with systematic feedback to local stakeholders and discussion of assumptions backing the modelling work. This approach is fundamentally adaptive in order to take into account the local stakeholders' preoccupations, perspectives and interests. In the past decade, it has been applied in many places globally (see for example D’aquino et al., 2003; Etienne, 2003) and at a dozen sites in Southeast Asia (Bousquet et al., 2005). Because ComMod researchers differ slightly in their theoretical perspective and consequently in the research methodology they embrace, the ones we adopted in this study are presented below.

The ComMod action research presented in this paper was conducted by the first, third and fifth authors of this paper (some ComMod researchers) in the context of the $\mathrm{PhD}$ thesis of the first author (the main facilitator of the ComMod process). The fourth author facilitated the gaming sessions in Thai language. The second author joined the team afterwards to conduct an external evaluation of this ComMod process, in addition to the evaluation conducted by the first author along the process. Therefore, in this paper, "we" means both the people who conducted this process and the people who analyzed it.

\section{Theoretical framework: a critical systems approach}

Systems thinking has enabled various disciplines to attain a more holistic, interdisciplinary perspective on reality. Nowadays, three major strands of systems thinking can be identified: hard, soft and critical (Flood and Romm, 1995). Soft systems thinking was developed in reaction to the technology oriented hard systems thinking which assumes that, to remain

\footnotetext{
${ }^{5}$ Approximately 40 researchers belonging to diverse organizations from diverse countries and with diverse disciplinary background
} 
objective, researchers should stay outside the system they are studying. Based on a constructionist epistemology, soft systems thinking focuses on the various interpretations of a given situation by stakeholders and emphasizes the need for collective learning among them (Checkland, 1981). So far, ComMod researchers have opted for a soft systems approach. In this experiment and in this paper, we opt for a critical systems perspective. Also based on a constructionist epistemology, critical systems thinking emerged in reaction to the failure of soft and hard systems thinking to deal with coercive situations and to address power imbalances among stakeholders (Ulrich, 2003). Core commitments in critical systems thinking include (Jackson, 2000):

- Critical awareness: a never-ending attempt to uncover hidden assumptions,

- Social awareness and human emancipation: to prevent coercion and exercise of power from distorting communication to promote a more equitable distribution of power,

- Complementarity: the acknowledgement that various systems approaches tend to provide different rationalities which complement each other.

Whereas the principle of critical awareness is already explicit in the current ComMod charter, social awareness and human emancipation are not. The objective of this contribution is to analyse the importance of power relations in a ComMod process and to reflect on the pertinence for ComMod researchers to use the critical systems approach.

To analyse the socio-ecological system and changes triggered by the ComMod intervention, we used the theoretical framework described on the Figure 1. The agrarian system theory (Mazoyer and Roudart, 1997) allowed us to apprehend the historical evolution of socioeconomic differentiation of the resource users and the emergence of different types of farming households, each characterized by specific socio-economic and agro-ecological constraints, interests and strategies (Trébuil and Dufumier, 1993). In particular, it provides insight in the differential economic power resources among various farmer types and their respective interests in the negotiation process.

Power theories enabled us to better understand stakeholder relations and interactions. We considered power as a relational concept. People may have power resources, but it is in the interaction that they exert power. Weber (1968) defined power as the chance that an individual in a social relationship can achieve his or her own will even against the resistance of others. This is a 'power over' form of power (Vermeulen, 2005). Rowlands (1995) describes it as 'zero-sum': the more power one person has, the less the other has. Classical dichotomies derived from this definition of power, seeing the powerful on one side and the 
powerless on the other, are problematic because they do not take into account 'the power of the powerless', and therefore deny the possibility of becoming empowered, as to empower means reinforcing an existing power. However, power is not a simple resource that people have or don't have. There are actually different kinds of resources used to exert different kinds of power forms as well as various possible relational mechanisms in power relationships. Resources to exert power can be categorized into three main types: (a) knowledge, (b) cultural norms and values attributing traditional, legal or charismatic authority to certain roles, and (c) physical resources such as money, natural resources or human resources and skills (Giddens, 1984; Van Paassen, 2004). Cultural differences such as the belonging to different ethnic groups fall into the second category, but they also have repercussions in the first and third ones. Boulding (1989) characterized power relations according to three mechanisms: the stick, the carrot and the hug. The stick and carrot are familiar metaphors, stick standing for force, and carrot for enticement. Both are coercive forms of power, i.e. 'power over' forms of power. The most innovative concept in Boulding's work is the hug because it provides a variable to look at the empowerment of the disadvantaged and marginalized. The hug is a way to describe integrative or cooperative forms of power, i.e. the power of people joining together and obeying the same principles. This corresponds to 'power to' and 'power from within' forms of power (Vermeulen, 2005). Counter power (the power to oppose the oppressors) can be seen as a form of cooperative power of the less powerful stakeholders.

Since our analysis of power relations took place in a context of decentralization, we distinguished two kinds of social interactions: the horizontal interactions among people within a community, and the vertical interactions between villagers and higher level institutions, with the key role of local leaders and representatives at the intersection of these two dimensions. Following Ribot (2001), we highlight the importance of their representation and downward accountability to achieve democratic decentralization.

Apart from a contextual analysis, we also studied the expressions of power relations during the ComMod process. In multi-stakeholder processes, there are several possible expressions of power (Faysse, 2006; Leeuwis, 2000), such as the power:

- To include certain people or not in the process;

- $\quad$ To stay away from the process;

- To make people aware of a certain issue, making it an issue-at-stake they want to discuss and change; 
- To impose one's ideas during the discussion by dominating and/or ignoring other people’s opinions;

- To control the implementation of decisions at a certain administrative level.

Powerful stakeholders often refrain from negotiating if they have a good BATNA (Best Alternative To a Negotiated Agreement, Fisher and Ury, 1981). In some cases, they only engage in negotiations once the other parties have increased their power base, or when they are forced to do so by powerful actors at a higher hierarchical level.

When negotiations start, the less powerful stakeholders need the capacity to defend their interests. Effective advocacy requires self-confidence, freedom to express oneself, access to information and a thorough understanding of the issue at stake. To attain this capacity, marginalized actors might need to be empowered. Rowlands (1995) identified three dimensions of empowerment corresponding to three different forms of power:

- Personal empowerment: development of self-confidence and personal capacities corresponding to what Vermeulen (2005) called 'power to',

- Relational empowerment: development of skills to influence relationships corresponding to the so-called 'power over' , and

- Collective empowerment: learning to work together to achieve more (a 'power from within').

Leeuwis (2000) proposed using negotiation theory as a theoretical assumption behind participatory processes to better handle power imbalances and social conflicts. Scholars in the field of negotiation commonly distinguish between compromise and integration (Follett, 1940, cited by Carnevale, 2006). This corresponds to some other authors' distinction between distributive and integrative negotiation (Rubin, 1994; van Woerkum et al., 1999; Leeuwis 2004). In a distributive negotiation, stakeholders tend to stick to their own positions, and finally each side gives up something, meeting midway between opening positions. They simply 'share the cake' in a zero-sum outcome. In contrast, in an integrative negotiation process, the stakeholders creatively reframe the problem to 'enlarge the cake' and identify 'win-win' solutions. This implies a collective learning process in which both sides look beyond their initial positioning to examine the underlying interests determining them. Leeuwis (2004) described a set of tasks necessary to achieve such integrative negotiation: learning about the current situation, increased awareness of a problem to be solved collectively, learning about other stakeholders' perceptions, collective re-phrasing of the nature of the problem, coordination of interests through identification and negotiation of new scenarios to solve the re-phrased problem. 
To end with, we referred to Ulrich's critical system perspective to analyse our own way to facilitate the multi-stakeholders process. This author suggests in particular that facilitators of multi-stakeholder processes should be aware of their own biases regarding social inequities and power asymmetries among stakeholders (Ulrich, 2003). Jackson (2000) adds critical system scientists take some distance to study power dynamics first, and then strategically choose for a facilitation method best fit to create awareness and empowerment of the marginalised. In the ComMod cycle described in this paper, the main facilitator was aware of her cultural-ideological stance favouring an equitable process. She structured the RGG and $\mathrm{ABM}$ in such a way that the position of the marginalized farmers became visible so they had a chance to voice and assert their interests.

\section{The ComMod action research methodology as applied in the $3^{\text {rd }}$ ComMod cycle in Mae Salaep, northern Thailand}

A cyclical ComMod process was conducted between 2002 and 2007 in the Akha village of Mae Salaep, Chiang Rai Province, upper northern Thailand. In this experiment, the main successive phases of a ComMod cycle were as follows: (i) characterization of the problem, (ii) converting this knowledge into a simulator, and (iii) participatory simulations to question the model assumptions and explore scenarios. We used two different simulation tools: roleplaying games (RPG) and agent-based models (ABM). RPG allows multiple stakeholders to interactively examine the complex systems of which they are part and to experientially test alternative scenarios and solutions to solve the issues-at-stake (Duke, 1974). But RPGs become costly and time consuming if stakeholders wish to try a spectrum of solutions or need to explore long-term effects of their decisions. To remove this constraint, it is possible to build an associated computerized ABM, similar to the RPG, which is more time-efficient in simulating scenarios. The RPG is then a way to 'open the black box of the model' as it allows the players to understand what the ABM is doing, to validate and criticize it (Barreteau et al., 2001).

The learning process stimulated by a given ComMod cycle may raise new questions to be examined in a following cycle with modified RPG and/or associated ABM. This is what happened in the present ComMod experiment (Figure 2). In a first cycle focusing on soil erosion risk (Trébuil et al., 2002), the participating villagers in Mae Salaep identified the expansion of perennial crops as a promising solution, and requested a second cycle focusing on the socio-economic constraints limiting their ability to invest in such crops (Barnaud et al., 
2008a). Later on, as these perennial crops required irrigation, the participants requested to explore water management issues in a third ComMod cycle which is the focus of this article.

This paper focuses on the third cycle, which started with an analysis of the agrarian and institutional aspects of the water problem: semi-structured interviews were conducted with two dozens of farmers representing the diversity of farming strategies in the village of Mae Salaep, the village headman and the key stakeholders of the sub-district administration (the TAO - Tambon Administrative Organization), i.e. the TAO village representatives, the TAO officers, and the president of the TAO council. The local knowledge acquired with these interviews was used to modify the previous RPG and ABM to focus on the water issue. These simulation tools (presented in details in Barnaud et al., 2007, 2008a, 2008c) integrated and highlighted the diversity of perspectives and interests regarding the water issue among the different types of farming households. These tools were used in a three-day participatory workshop organized in the village. 12 villagers had been selected and invited by the research team. The main selection criteria were as follows: they represented the diversity of farming strategies in the village regarding the water issue, they were potentially able to defend their interests (communication skills, self confidence reinforced by the presence of closed acquaintances), and the participants of the first and second cycle were selected in priority to ensure the continuity of the whole ComMod process..

On the first day, gaming sessions were organized with the 12 villagers playing a role similar to their real life situation. After a first gaming session played with rules corresponding to the current water use situation, a collective debriefing was organized for the participants to discuss the problems encountered in this gaming session and their possible solutions. Then the facilitator suggested to the 12 villagers-players to present their preferred solution to the TAO president which had also been invited to the workshop. In the afternoon, a second gaming session allowed the villagers to further explore this potential solution by modifying the initial rules of the game. On the second day of the workshop, individual interviews were conducted with the 12 villagers-players to compare researchers' and participants'representations of the situation, to better understand players' behaviour during the gaming sessions, to learn about their individual opinions regarding the collectively discussed issues and to assess the shortterm learning effects of the RPG sessions. On the third day, participatory ABM simulations were conducted in a plenary session with the 12 participants to allow them to further reflect on their preferred scenarios. Three weeks and three months later, more ABM participatory simulations were conducted within smaller and more homogenous groups to accompany the 
on-going discussions in the village (beyond the 12 participants) which had been stimulated by the three-day workshop.

To assess the dynamic and the effects of the ComMod process, we adopted an interpretive approach, trying to interpret what the participants think and why they act the way they act.

Data on cognitive changes triggered by the ComMod process were obtained via semistructured individual interviews of the 12 participants conducted before the workshop and one day, three weeks and three months after the workshop. These interviews aimed to assess the evolution of the following indicators:

- Stakeholders' perceptions of the issue,

- Their perceptions of other stakeholders and their interactions with them,

- Their perceptions of the possible scenarios to mitigate the problem at stake.

The results of these interviews were analyzed using Atlas.ti, a software facilitating the qualitative analysis of texts.

The analysis of the collective dynamics of the group was based on observations of the participants' behaviour and discourses during the gaming sessions and group debates. Three researchers were observers during the workshop and took note of all the features which seemed interesting to them. A debriefing was organized afterwards with the rest of the facilitation team. Moreover, all the group sessions were video recorded. These videos were not systematically analyzed but their visioning helped to better understand some specific events or to identify elements which would have been overlooked by the observers.

The results of this analysis of the ComMod process are presented in the next sections.

\section{Ecological, socio-political and cultural context}

\section{Water management issue}

The local irrigation system uses gravity through a network of small PVC pipes connected to the creeks, each creek providing enough water to irrigate from one to three plantations. Due to the recent expansion of irrigated lychee and Oolong tea plantations and the increasing water shortage, social tensions about unequal access to water have heightened within the community. This issue concerned various stakeholders having specific interests, embedded in a specific cultural context and a complex network of power relationships. 


\section{Main types of farming households}

The integration of farming households into the market economy has led to extensive socioeconomic differentiation (Table 1). Well-off type C farmers are well-off farmers who belong to influential clans of first settlers and sit on the traditional council of elders. Fifteen years ago, when they invested in the first lychee plantations and irrigation facilities in the village, they claimed that the first-come-first-served rule was an ancestral custom to regulate access to water. This rule stipulates that once a farmer has set up water pipes in a creek, other villagers cannot get water from the upstream section. As a result, only this minority of well-off farmers currently has access to water.

Type A and B households belong to smaller and less influential clans. Most of them do not openly question the first-come-first-served rule, including the farmers who invested in lychee plantations and cannot irrigate them. Not only because they do not want to break what is seen as an ancestral community rule, but also because they are (partly) dependent on type C clans, from whom they borrow money or work as hired labourers. In terms of power relations, type $\mathrm{C}$ farmers use both traditional authority and physical resources to exert power through enticement over type A and type B farmers (Figure 3).

\section{The Tambon Administrative Organization (TAO)}

Villagers asked ComMod researchers to explore the water management issue, and requested the participation of the Tambon (sub-district) Administrative Organization (TAO), because it funds local projects such as the construction of small-scale water infrastructure. These recently empowered administrations, with their council of elected villagers (two representatives per village), have the responsibility to promote participatory decentralization in rural Thailand (Arghiros, 2001). However, there are still obstacles to achieving this desired aim.

Despite the formal decentralisation, Thailand's bureaucracy still adheres to a hierarchical, top-down institutional culture. In our case study, the TAO president used the participatory discourse, but as we will see later, there was a sharp contrast between the discourse and her actual practices, as is often the case in participatory projects (Pijnenburg, 2004). As for the two TAO representatives, they belong to the local economic elite and their downward accountability to the community was openly questioned as they were regularly accused of taking advantage of their position to serve their own clan's interests. They felt much greater allegiance to upward accountability and defined their role as top-down relays 
between the sub-district administrators and the villagers. As for the villagers, very few were aware of the role they could play in the proposition and realisation of TAO funded projects.

\section{Village leaders and representatives}

Two leaders played a key role in this ComMod cycle. The first one is a TAO representative. He had recently concluded a deal with an external investor, who bought a large piece of land in the village to plant high value Oolong tea. As this plantation needed a substantial quantity of irrigation water, he was likely to defend his personal interest in the ComMod process. The religious leader of the village Christian community (representing $60 \%$ of the village population) also played a key role. He was not only respected as a religious leader but also as a knowledgeable innovator and leader in agricultural matters, actively supporting poor households facing difficulties. His charisma created a federative form of power within the Christian community and among poor villagers. He was the first to raise the idea of using ComMod to discuss water sharing problems.

\section{Cultural issues that played a role in the learning process}

Several cultural aspects of the context played a key role in the power games and the collective dynamic of the ComMod process. First, as mentioned before, there was the cultural issue of a western ComMod researcher openly embracing the critical system theory, highligting the situation of the poor in the RPG and ABM simulations. This is all the more important since this participatory process was conducted in a society in which people evade public confrontation and not very used to open participatory deliberations. Akha people do not like conflicts (traditionally, when a conflict would occur among people in a settlement, the whole community would move and settle somewhere else) and although these values tend to erode over time, Akha people remain very much community-oriented (Goodman, 1996). Moreover, the conversion to Christian religion of half of the villagers of this community (villagers from the upper hamlet) in the last 20 years makes the cultural picture of this participatory process even more plural and complex. There was no real contradiction or conflicts of perspectives between the animist and Christian parts of the community (the upper and the down hamlets), since most of villagers who converted to Christian religion did so more for practical reasons than for ideological reasons ("because every one in this hamlet is Christian" and "because there are less rituals and donations" were the main reasons given by the villagers from the upper hamlet). However, the religious beliefs of the Christian leader influenced his views, discourses and actions in favour of the poorest of the community. Lastly, ethnic minorities 
living in the uplands of Northern Thailand (the Golden Triangle) have long been considered by the Thai majority as "backwards" people, if not dangerous. Opium dealers, communists, forest destroyers: these clichés about upland ethnic minorities are very common among Thai people and in Thai administrations (Ganjanapan, 1997). In our case study, if the president of the TAO council was Akha, the TAO officers were all Thai government employees. Their perception of the villagers remained influenced by the above-mentioned clichés. This cultural dimension reinforced stereotyping, limited communication and power asymmetries between villagers and TAO officers.

\section{Analysis of power dynamics in the learning and negotiation process}

In this section we analyze the influence and mechanisms of power games at key stages of the ComMod mediated cross-cultural learning and negotiation process.

\section{Structure of the game increased awareness of a problem to be solved collectively}

In the first gaming session, the players acted as in reality: the well-off farmers hurried to install water pipes, and did not allow others access to water from the upstream sections. This highlighted the current conflict caused by the first-come-first-served rule and increased the participants' awareness of the problem, its urgency and the need to solve it collectively. As the religious leader said, "the game showed everyone we need to change the water allocation rules. No need to say anything.”

This was a key phase in the negotiation process since it determined whose interests would be on the agenda. Before the gaming sessions, well-off (type C) farmers with access to water denied the water problem. They repeatedly noted: 'there is no water problem in the village, everything is all right.' They obviously had a good BATNA (Best Alternative to Negotiated Agreement); a clear interest in maintaining the statu quo rather than exploring the water problem. If the ComMod process had started with a more classical meeting in which discussions prevail, the water-sharing problem might not have emerged as the elite would have been able to dominate discussion and agenda-setting. The game, however, facilitated a different form of communication, which allowed less powerful villagers to raise their problem and to create a collective awareness of its existence.

\section{Exchanges of perceptions on the problem}

The ComMod process stimulated participants to share perspectives on the water problem. Most of participants said the game allowed them to better understand other villagers' 
situations, problems and/or perceptions (table 2). In particular, some well-off (type C) farmers with water access realized that the first-come-first-served rule would create more and more social tensions under the current expansion of irrigated plantations. Two type A and B farmers said they realized that "many of [them] had the same problem" (the lack of access to water). At first sight, this may be surprising since villagers in a small community tend to know each other, but as one participant said: "in every day life, every one goes to his fields; we do not have such opportunities to jointly discuss issues.” Moreover, several participants noted the game provided some distance from reality and an open playful atmosphere, which both facilitated exchanges about the sensitive and conflicting water issue. This was particularly important in the Akha cultural context of conflict avoidance.

\section{Non-threatening re-framing by integrative negotiation of solutions}

The framing of the problem is a crucial step in a negotiation process as it orients people towards certain kinds of solutions (Leeuwis, 2004). In this case, when being asked by the facilitator to identify the problem, none of the players mentioned the first-come-first-served rule. The TAO representative dominated the discussions emphasizing the lack of water and suggesting the construction of a single large reservoir above the village catchment. Other participants were sceptical about this proposition since they feared it would only benefit a minority of farmers, but they did not say anything at this stage. The Christian leader kept silent and only expressed himself when the facilitator explicitly asked for other suggestions. As he would explain later, he knew that it was impossible to question directly the first-comefirst-served rule because well-off clans would have not accepted it. Furthermore, a direct confrontation over this rule would have generated a zero-sum bargaining process in which the villagers would have fought to 'share the cake'; a distributive mode of negotiation in which small farmers had no chance to change the situation. Therefore, he suggested increasing the amount of water available to be able to share it with more people. By creating a win-win situation, he had a chance of getting the attention and support of powerful stakeholders. He suggested building small weirs in several creeks and sharing the water within several water user groups. In interviews, he and other participants interestingly explained that "without new infrastructures, it is impossible to change existing rules.” All participants (except one whose plots were above the creeks) raised their hand to vote in favour of this integrative solution. It is important to notice here that the community-oriented Akha way of life deeply influenced the trajectory of this creative learning process. The importance of peace and consensus within 
the community favoured the acceptance of this win-win solution by the well-off farmers despite their interest in statu quo.

\section{Importance of discussions behind the scenes}

The above-mentioned proposal (several small weirs) was tested in the second gaming session. It stimulated discussions, further supported by hybrid Agent Based Model (ABM) simulations (Barnaud el al, 2008c), regarding how to share water among beneficiaries of the weirs. At the first plenary ABM simulations, the TAO representative used his communication skills and authority to impose his idea, i.e. to share water in amounts proportional to the farmers' plantation size. But three weeks later, when new sets of simulations were organized within smaller and more homogeneous groups, participants had continued discussions among them after the workshop on the water sharing rules and they immediately agreed on sharing equal amounts of water. They added the possibility to temporarily lend out water rights to other farmers in case of excess of water. This shift illustrates the importance of discussions "behind the scenes” in-between ComMod workshops. In particular, as explained below, much of the process of empowerment of the marginalized which progressively led to the emergence of pro-poor solutions occurred "behind the scenes". Moreover, once more at this stage, the procommunity dimension of the Akha culture was influential. Indeed, interviews revealed that an old and respected farmer belonging to a well-off and influential clan said after the workshop to other villagers that he was in favour of an equal way of sharing the water to preserve peace in the community.

\section{Reaching agreement}

In a decision-making process, the phase at which the protagonists reach agreement is a determining one. At this stage, in spite of previous phases of improved communication and exchange of perspectives, influential participants (consciously or unconsciously) can exert power to impose their point of view (Van der Veen 2000). This can lead to a simple reproduction of initial power inequities. In our case study, three months after the last ComMod workshop, the TAO representative felt inclined to present his initial idea of the single reservoir to the TAO council rather than the agreed upon solution of several weirs. However, ten months later, the TAO representative and the Christian leader had started to collaborate and they had proposed the TAO council a project that took into account the interests of small farmers with no access to water. 


\section{A process which empowered the marginalized}

In spite of initial power inequities, the interests of the marginalized were progressively taken into account in the negotiation arena. This was achieved through individual and collective empowerment. Along the process, the participants became more and more aware and selfconfident about the water issue and the TAO village projects. In the interviews, the ideas they expressed about theses issues were more and more elaborate, and during the group discussions, they more and more dared to express their opinion. The development of individual self-confidence is particularly important in the cultural context of northern Thailand, where prejudices against ethnic minorities persist and strongly affect people's notion of self-efficacy. Several villagers (in particular type A farmers) believed that they had neither valuable ideas nor the skills to express them. In this light, it is remarkable that a female participant noted: 'I am so proud. I did not know that I would be able to play the game, to think by myself about solutions'. Furthermore, evaluation interviews revealed that the feeling of collective empowerment was one of the stronger effects of the ComMod process. Most of the participants explained the ComMod process made them realize that collectively they were 'stronger' or 'more intelligent' than individually. "Without the game, everyone thinks and act on his own. With the game, we discuss and think together, and we can find better solutions”, said a B participant. And one step further: less powerful stakeholders realised they could join a charismatic leader to create an alliance and counter power. Most of this counter power was built "behind the scenes" in-between and after the ComMod workshops.

\section{Potential and limits of this critical ComMod process to level the playing field}

In this ComMod process, as facilitators, we adopted a critical attitude, i.e. we explicitly took into account power asymmetries to try to facilitate an equitable concerted process. In this section, we identify and discuss the strengths and weaknesses of our cultural-embedded methodological choices. Final questions were: were our methods able to deal with power inequities and include the marginalized? What was the legitimacy of these cultural-embedded choices?

\section{Strengths}

First, we argue the need for an initial analysis of power asymmetries among stakeholders in the local socio-political context. Among practitioners of participatory approaches there is a 
debate about the kind of initial analysis needed before starting a participatory process. In our experiment, the initial analysis allowed us to identify constraints for an equitable concerted process and to mitigate them by adapting the methods and tools we used. A methodological proposition for such an initial analysis is available in (Barnaud et al., 2008b). The formulation of ComMod activities were then guided by the concern for the less powerful actors.

The careful selection of participants was a determining factor to go towards the creation of a level playing field. Edmunds and Wollenberg (2001) argue not all stakeholders should systematically participate in a multi-stakeholder process. If not yet empowered prior to such an exercise, the less powerful ones might not be able to properly defend their interests. This is the reason why we started the ComMod process at the village level, only integrating stakeholders of higher institutional levels when villagers felt comfortable and explicitly requested the presence of these decision-makers. When selecting the participants, we also tried to avoid the representation of a category of stakeholders by a single, shy person. For example, several women would have felt intimidated and shy when being alone, but in company of acquaintances they were more self-confident and talkative. Moreover, ComMod provides an opportunity to meet and exchange to a specific set of participants; the selection of participants hence influences the alliances that emerge during the process. For example, the identification and the active involvement of key stakeholders such as the Christian leader, who was particularly bottom-up minded and had sufficient charismatic authority to stimulate people to follow him, proved to be crucial.

To increase the self-confidence and capacity of participants to express their opinions, they should genuinely understand the model in use and for so participate in its construction. Some ComMod researchers think it is better not to prepare a model and RPG in advance, so as not to impose their science-based perspective, but to build the conceptual model from scratch in plenary discussions with the stakeholders. However, in this ComMod experiment, we considered in plenary discussions village elite would probably impose their perception and set the agenda, so it was decided to construct the model from the information gathered via individual interviews with farmers of all farm categories. Disadvantage of this approach is that participants need time to build self-confidence before they dare to criticise the researchers' model. But advantage is that the researchers can take care to represent all stakeholders' interests, also those of the marginalized, in the RPG and ABM. In this way, we could put the issues-at-stake for the marginalized on the agenda. Despite the Akha culture of 
conflict avoidance, it was accepted the ComMod scientist visualised the confronting situation via the RPG and ABM simulations. This enabled the farmers to tackle the issue.

Wollenberg et al. (2001) underline participatory approaches often fail to tackle power inequities because they try to reach a consensus too fast. This experiment demonstrated how important it was to move beyond the first apparent consensus when facilitating the plenary discussions, as it often reflected the interest of the most powerful participants. This is especially important in Akha and Thai cultures that emphasize respect for hierarchy. To move beyond the 'initial public consensus', we also conducted individual interviews and small group discussions alongside plenary discussions. This provided the participants the opportunity to freely express and further articulate their opinions. Typically, in a plenary session, participants stated they lacked water as they had no money to buy PVC pipes, while in individual interviews the same persons quickly incriminated the first-come-first-served rule.

As most conflicts are not solved in public but behind the scenes (Fisher and Ury, 1981), the continual and iterative nature of the ComMod process is a feature favouring the re-framing of matter, gradual articulation of opinions, empowerment of less vocal and the integration of multiple interests. If the ComMod process had stopped after a single gaming workshop, we would have missed the opportunity to monitor and support the individual and collective empowerment processes needed to attain a fair village discussion and a more equitable solution.

\section{Limits and perspectives for improvement}

All the factors mentioned above allowed some usually voiceless people to participate in the elaboration of a new project at the village level. However, the question remains what impact this will actually have on the life of this community? What perspectives for improvements did this experiment suggest?

Only 12 villagers participated to the third ComMod cycle on water management. They were selected by the research team to be representative of the different types of farming households in the village, but they were not considered by the other villagers as their representatives or spokespersons. Therefore, no village-level decisions could be formally taken during the ComMod workshops. The discussions among the 12 participants more or less diffused across other villagers since a TAO village project was finally designed at the village level. However, several participants mentioned that 'those who played the game now think differently, in a more cooperative way, but those who did not play the game do not all think the same way.' 
This was considered a main limit of this ComMod process. However, it is difficult to organize gaming sessions with more than 15-20 participants, and it would be too costly to multiply their number. A first solution could be a game that the villagers could play autonomously without guidance of researchers. The effect of multiple use of such a game highly depends on the commitment and training of a local facilitator. To attain a fair discussion it is important to have a skilled facilitator, readily available to regularly play the game and closely monitor village discussions, working on empowerment of the marginalised and integration of perspectives. Such a 'champion' may be difficult to find. The religious leader was initially identified as such a potential local facilitator but in spite of his general support of the ComMod approach, he finally refused to ensure this heavy task. The TAO representative expressed his interest to be such a facilitator, but the research team considered that the risk was too high that he manipulates the process to serve his own interests. Another option could be to call village meetings after each workshop to present and discuss the results in an interactive way to all villagers. A new combination of RPG and ABM was tested for such a purpose in a ComMod experiment conducted in another province of northern Thailand (Barnaud et al., 2008b).

Second, this ComMod experiment failed to stimulate a genuine bottom-up dialogue between the villagers and their TAO president. If the process reinforced the villagers' ability to make creative and concerted suggestions to the TAO, it did not reinforce the ability of TAO officers and managers to genuinely listen to villagers. In spite of her discourse on participation, the TAO president arrived late at the ComMod workshop and discouraged rather than listened to the villagers. Later on, when the villagers finally submitted their project to the TAO council, she refused to fund it. Greater efforts should be pursued to know the front-office and backoffice discourse of these key actors, to raise their awareness and interest in the potential of a deliberative ComMod process enabling them to arrive at better informed, sustainable decisions. At this stage of the decentralisation process, most Thai organisations and officers are not yet ready to participate in a truly bottom-up dialogue. The training of a new generation of local administrators in the potential, limits and risks of participatory approaches may change their appreciation and promote their critical use.

\section{Conclusion}

This experiment illustrates the pertinence of taking power games into account in participatory processes. The case shows it is not always enough to put stakeholders together around a table to achieve a fair and equitable concerted process. This paper calls for a critical companion 
modelling approach, paying attention to power relations, in which the socio-political system is carefully analysed and monitored to identify the main constraints militating against an equitable concerted process, and to creatively adapt existing methods and tools to mitigate them.

However, such a posture raises several questions. Here a foreign process designer used her cultural space for manoeuvre to put the issue of equity on the agenda. Beside the practical question of the costs and feasibility of a preliminary in-depth analysis of power relations, it raises the key question of the facilitators' involvement and commitment. Is it legitimate for researchers to be involved in processes that modify power games in the negotiation arena by empowering the powerless participants? If not, should they adopt a neutral posture? But this experiment shows that facilitators' neutrality is an illusion: overlooking power relations entails the risk of increasing social inequities. Moreover, claiming facilitators' neutrality is insidious as unconscious choices drive the process without being examined. Systematically expressing and examining the facilitators' choices is a demanding but wiser course to adopt. If facilitators make explicit their cultural or ideological embedded biases and methodological choices, these choices can be rejected or accepted as legitimate by stakeholders. This way, the social legitimacy of the process can be progressively built, being in itself an important result of the cross-cultural learning process.

\section{Acknowledgements}

The authors gratefully thank the Challenge Program Water and Food of the CGIAR, the Asia IT\&C Initiative of the European Union and the Thai-French Bilateral Scientific Cooperation Programme for their financial support.

\section{References}

Arghiros, D. (2001) Democracy, Development and Decentralization in Provincial Thailand. Richmond: Curzon and Nordic Institute of Asian Studies.

Barnaud, C., T. Promburom, G. Trébuil and F. Bousquet (2007) 'Evolving simulation and gaming to support collective watershed management in mountainous northern Thailand', Simulation Gaming 38: 398-420.

Barnaud, C., Bousquet, F. and G. Trébuil (2008a) 'Multi-Agent Simulations to Explore Rules for Rural Credit Management in a Highland Farming Community of Northern Thailand', Ecological Economics 66(4): 615-627.

Barnaud, C., Trébuil, G., Dumrongrojwatthana, P. and J. Marie (2008b) 'Area Study prior to Companion Modelling to Integrate Multiple Interests in Upper Watershed Management of Northern Thailand', Southeast Asian Studies 45(4): 559-585.

Barnaud C., Promburom P., Trébuil G. et F. Bousquet. (2008c). Interactive models to catalyze collective water management: a companion modeling approach in northern Thailand. 
Proceedings of the Second International Forum on Water and Food (IFWF2). Addis Ababa, Ethiopia, CPWF-CGRAI, November 2008.

Barreteau, O., F. Bousquet and J. Attonaty (2001) 'Role-playing games for opening the black box of multi-agent systems: method and lessons of its application to Senegal River valley irrigated systems', Journal of Artificial Societies and Social Simulation 4(2). http://jasss.soc.surrey.ac.uk/4/2/5.html (accessed 24 September 2007)

Barreteau, O., M. Antona, P. D’aquino, S. Aubert, S. Boissau, F. Bousquet et al. (2003) 'Our companion modelling approach', Journal of Artificial Societies and Social Simulation 6(1). http://jasss.soc.surrey.ac.uk/6/2/1.html (accessed 24 September 2007)

Boulding, K. E. (1989) Three Faces of Power. Newbury Park: Sage Publications.

Bousquet, F., O. Barreteau, C. Le Page, C. Mullon and J. Weber (1999) 'An environmental modelling approach. The use of multi-agents simulations', in F. Blasco and A. Weill (eds) Advances in Environmental and Ecological Modelling, pp 113-122. Paris: Elsevier.

Bousquet, F., G. Trébuil and B. Hardy (eds) (2005) Companion Modeling and Multi-Agent Systems for Integrated Natural Resource Management in Asia. Los Baños, Laguna, Philippines: International Rice Research Institute; Montpellier, France: CIRAD.

Checkland, P. (1981) Systems thinking, systems practice. Chichester: John Wiley and Sons.

Carnevale, J.P. (2006) 'Creativity in the outcomes of conflict' in M. Deutsch, P.T. Coleman and E.C. Marcus (eds.) Handbook of conflict resolution: theory and practice, $2^{\text {nd }}$ edition, pp 414-435. San Francisco: Jossey-Bass.

D'Aquino, P., C. Le Page, F. Bousquet, A. Bah (2003) 'Using Self-Designed Role-Playing Games and a Multi-Agent System to Empower a Local Decision-Making Process for Land Use Management: The SelfCormas Experiment in Senegal', Journal of Artificial Societies and Social Simulation 6 (3). http://jasss.soc.surrey.ac.uk/6/3/5.html (accessed 24 September 2007)

Duke, R.D. (1974). Gaming: The Future's Language. New York: SAGE Publications.

Edmunds, D. and E. Wollenberg (2001) 'A Strategic Approach to Multistakeholder Negociations', Development and Change 32(2001): 231-253.

Etienne, M. (2003) 'Sylvopast : a multiple target role playing game to assess negotiation processes in sylvopastoral management planning', Journal of Artificial Societies and Social Simulation 6 (2). http://jasss.soc.surrey.ac.uk/6/2/5.html (accessed 24 September 2007)

Faysse, N. (2006) 'Troubles on the way: an analysis of the challenges faced by multistakeholder platforms', Natural Resources Forum 30: 219-229.

Fisher, R. and B. Ury (1981) Getting To Yes: Negotiating Agreement Without Giving In. Boston: Houghton Mifflin.

Flood, R.L. and N.R.A. Romm (1995) 'Enhancing the process of methodology choice in Total Systems Intervention (TSI) and improving chances of tackling coercion', Systems Practice 8(4): 377-408.

Follett, M.P. (1940) 'Constructive Conflict', in H.C. Metcalf and L. Urwick, L. (eds.) Dynamic administration: The Collected Papers of Mary Parker Follett, pp. 30-49. New York: Harper.

Ganjanapan, A. (1997). The politics of environment in Northern Thailand: ethnicity and highland development programs. In P. Hirsch (Ed.), Seing forest for trees: environment and environmentalism in Thailand (pp. 202-221). Chiang Mai: Silkworm books.

Giddens, A. (1984) The Constitution of Society: Outline of the Theory of Structuration. Cambridge: Cambridge Polity Press.

Goodman, J. (1996). Meet the Akhas. Bangkok : White Lotus. 
Jackson, M. C. (2000) Systems approaches to management. New York: Kluwer Academic.

Leeuwis, C. (2000) 'Reconceptualizing Participation for Sustainable Rural Development: Towards a Negotiation Approach', Development and change 31: 031-059.

Leeuwis, C. (2004) Communication for rural innovation. Rethinking agricultural extension. Oxford: Blackwell publishing Ltd.

Mazoyer, M. and L. Roudart (1997) Histoire des agricultures du monde: du néolithique à la crise contemporaine (A history of world agriculture: from the neolithic age to the current crisis). Paris: Éditions du Seuil.

McKinnon, J. and B. Vienne (1989) Hill tribes today. Bangkok: White Lotus-Orstom.

Nelson, N., \& Wright, S. (1995). Participation and power. In N. Nelson \& S. Wright (Eds.), Power and participatory development. Theory and Practice (pp. 1-18). London: Intermediate Technology Publications.

Pijnenburg, B. (2004) 'Keeping it vague. Discourses and practices of participation in rural Mozambique'. PhD dissertation, Wageningen University, Wageningen.

Pretty, J. N. (1995) 'Participatory learning for sustainable agriculture', World Development 23(8): 1247-1263.

Ramirez, R. (2001) 'Understanding the approaches for accommodating multiple stakeholders' interests', International Journal of Agricultural Resources, Governance and Ecology 1(3/4): 264-285.

Ribot, J. C. (2001) 'Integral local development: accommodating multiple interests through entrustment and accountable representation', International Journal of Agricultural Resources, Governance and Ecology 1 (3/4): 327-350.

Röling, N. G. and M. A. Wagemakers (1998) 'A new practise: facilitating sustainable agriculture', in N. G. Röling and M. A. Wagemakers (eds) Facilitating Sustainable Agriculture: Participatory learning and adaptive management in times of environmental uncertainty, pp 3-22. Cambridge: Cambridge University Press.

Rowlands, J. (1995) 'Empowerment examined', Development in Practice 5(2): 101-107.

Rubin, J.Z (1994). 'Models of conflict management', Journal of social issues 50(1): 33-45.

Rutherford, J. (2002) 'Institutions, Impacts and responses in the agrarian transformation of the mountains of northern Thailand', in X. Jianchu and S. Mikesell (eds) Lanscapes of diversity, pp 55-78. Lijiang: Yunnan Science and Technology Press.

Trébuil, G. and M. Dufumier (1993) 'Regional Agrarian Systems and Sustainability of Agricultural Production Systems in Thailand', Journal of the Asian Farming Systems Association 1(4): 557-568.

Trébuil G., B. Shinawatra-Ekasingh, F. Bousquet and C. Thong-Ngam (2002) 'Multi-Agent Systems Companion Modeling for Integrated Watershed Management: A Northern Thailand Experience', in X. Jianchu and S. Mikesell (eds) Landscapes of diversity, pp 349-358. Lijiang: Yunnan Science and Technology Press.

Ulrich, W. (2003) 'Beyond methodology choice: critical systems thinking as critically systemic discourse', Journal of the Operational Research Society 54: 325-342.

Van der Veen, R. G. W. (2000) 'Learning natural resource management', in I. Guijt, J. A. Berdegué and M. Loevinsohn (eds) Deepening the basis of rural resource management, proceedings of a workshop, pp 15-21. The Hague: ISNAR and RIMISP.

Van Paassen, A. (2004) Bridging the gap: computer model enhanced learning about natural resource management in Burkina Faso. Wageningen: Wageningen University and Research Center.

Van Woerkum C., Kuiper D., Bos E. (1999) Communicatie en innovatie : een inleiding. Alphen aan den Rijn : Samsom. 
Vermeulen, S. (2005) Power Tools: Handbook to tools and resources for policy influence in natural resource management. London: International Institute for Environment \& Development.

Weber, M. (1968) Economy and Society: An Outline of Interpretive Sociology. New York: Bedminster Press.

Webler, T. (1999) 'The Craft and Theory of Public Participation', Journal of Risk Research 2(1): 55-71.

Wollenberg, E., J. Anderson, D. Edmunds (2001) 'Pluralism and the less powerful: accommodating multiple interests in local forest management', International Journal of Agricultural Resources, Governance and Ecology 1(3/4): 199-222. 
Figure 1. Conceptual analytical framework

Critical learning system

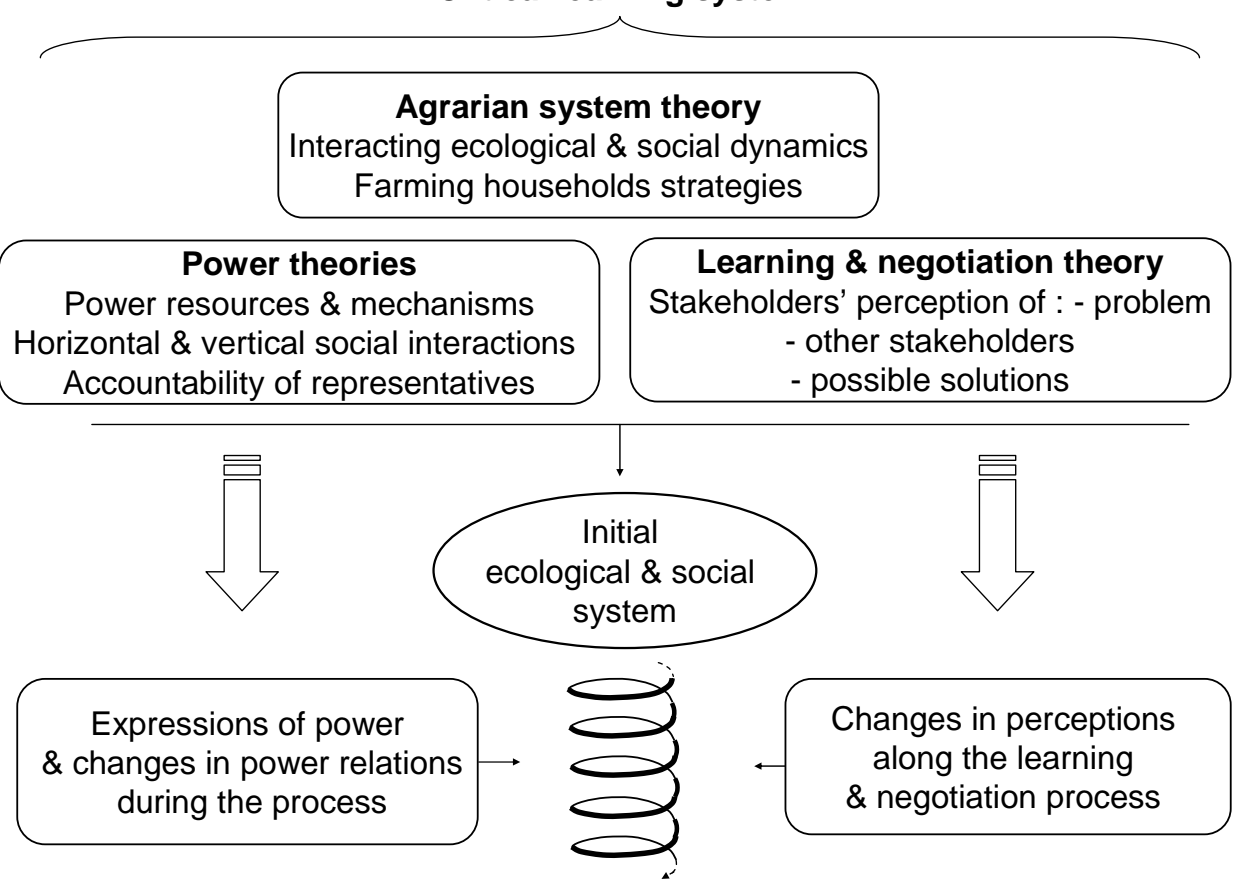

Commodod 
Figure 2. The three successive ComMod cycles implemented between 2002 and 2005 in Mae Salaep

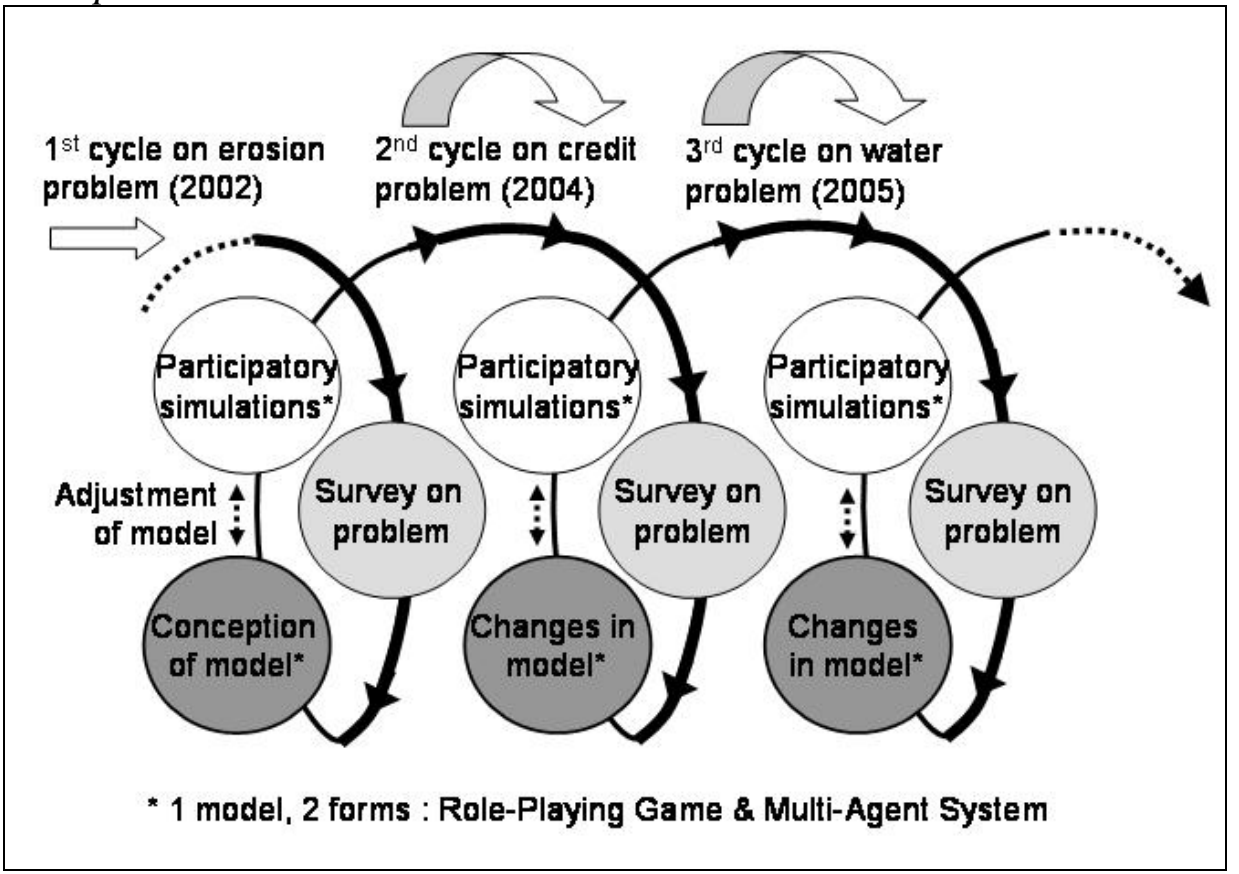


Table 1. Characteristics of the main types of farming households in Mae Salaep

\begin{tabular}{|c|c|c|c|}
\hline Farm type & $\begin{array}{l}\text { A. Vulnerable landless } \\
\text { or very smallholders }\end{array}$ & $\begin{array}{l}\text { B. Self-sufficient \& } \\
\text { medium-sized farms }\end{array}$ & $\begin{array}{l}\text { C. Relatively large \& } \\
\text { diversified farms }\end{array}$ \\
\hline Size (ha/labour ${ }^{(1)}$ ) & $0.4-0.8$ & $0.8-2.4$ & $1.3-3.2$ \\
\hline Main crops & Maize (for cash) & $\begin{array}{l}\text { Upland rice (for family } \\
\text { consumption), maize, } \\
\text { small and rainfed } \\
\text { plantations of Assam } \\
\text { tea or lychee }\end{array}$ & $\begin{array}{l}\text { Paddy rice (for family } \\
\text { consumption), maize, } \\
\text { extensive irrigated } \\
\text { plantations of lychee, } \\
\text { Oolong and/or Assam } \\
\text { tea }\end{array}$ \\
\hline Off-farm employment & $\begin{array}{l}\text { To meet basic family } \\
\text { needs }\end{array}$ & $\begin{array}{l}\text { To mitigate fluctuations } \\
\text { of farming incomes }\end{array}$ & $\begin{array}{l}\text { To raise cash and invest } \\
\text { on the farm }\end{array}$ \\
\hline $\begin{array}{l}\text { Total annual household } \\
\text { cash income (US } \\
\text { Dollars/year) }^{(2)}\end{array}$ & 200 & 420 & 1,160 \\
\hline Investment capacity & Nil & Weak & Significant \\
\hline
\end{tabular}

(1) 1 labour unit is equivalent to 300 working days per year.

${ }^{(2)}$ In 2005, the local household survival threshold (to meet the household basic needs) was assessed at 210 US dollars/household/year, and the annual income from minimum wages paid to city workers was 750 US dollars/year. 
Figure 3. Initial power relations among the local participants in the ComMod process implemented in 2005 at Mae Salaep.

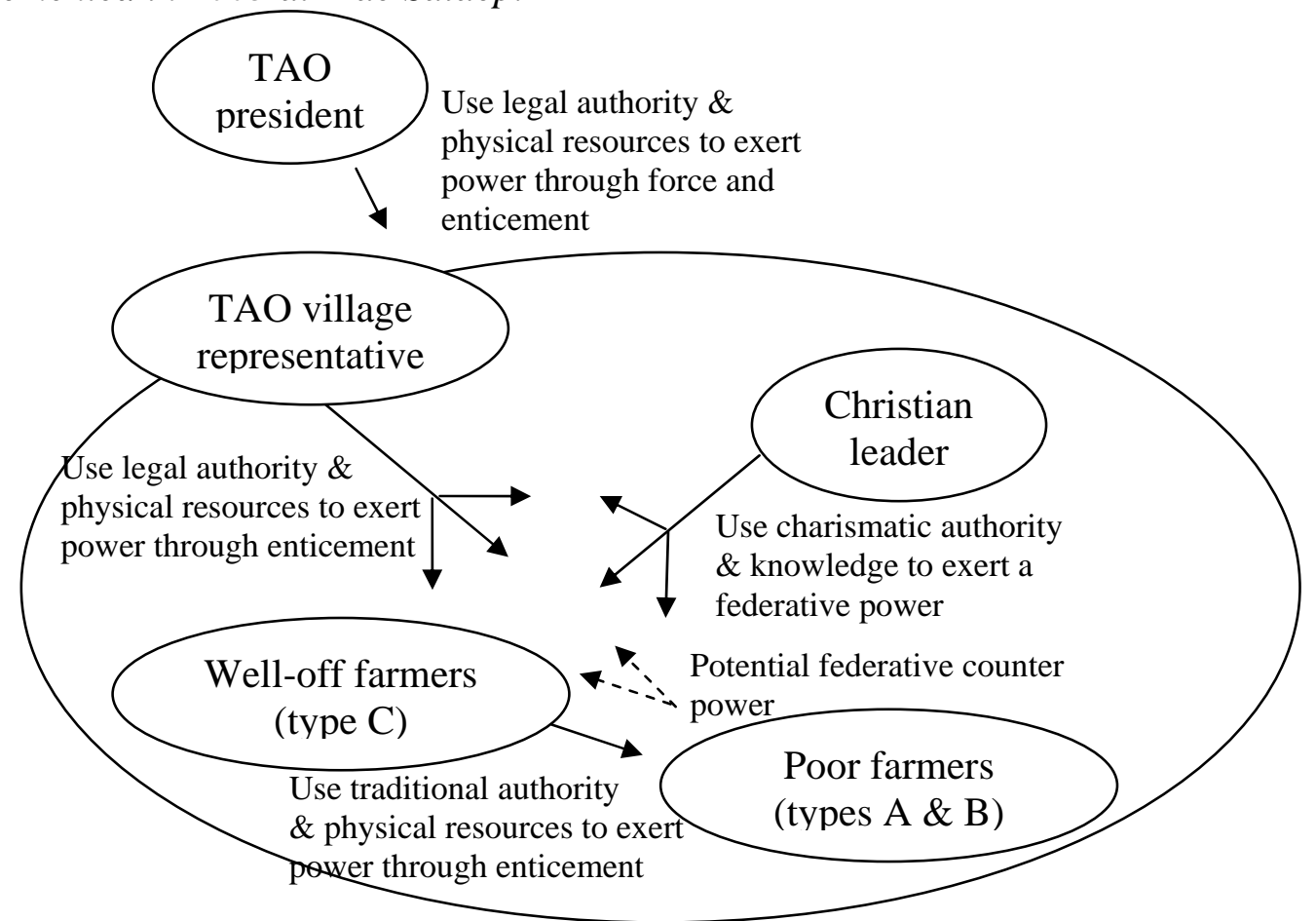


Table 2. Participants' answers to the question "did the process allow you to learn something about other participants?”

\begin{tabular}{|c|c|}
\hline Categories of answers & $\begin{array}{c}\text { Number of participants who } \\
\text { gave this answer } \\
\text { (types of farmers) }\end{array}$ \\
\hline $\begin{array}{l}\text { Realized that when all people discuss together, they can find } \\
\text { better solutions }\end{array}$ & $\begin{array}{c}4 \\
(1 A, 2 B, 1 C)\end{array}$ \\
\hline $\begin{array}{l}\text { Realized that other people had problems similar to his/her } \\
\text { problems regarding water }\end{array}$ & $\begin{array}{c}2 \\
(1 A, 1 B)\end{array}$ \\
\hline $\begin{array}{l}\text { Better understood the situation and perception of other } \\
\text { participants regarding water }\end{array}$ & $\begin{array}{c}4 \\
(2 B, 2 C)\end{array}$ \\
\hline $\begin{array}{l}\text { Better understood the practices of other participants } \\
\text { regarding water }\end{array}$ & $\begin{array}{c}2 \\
(2 B)\end{array}$ \\
\hline Did not learn much about other participants & $\begin{array}{c}1 \\
(1 \mathrm{~A})\end{array}$ \\
\hline
\end{tabular}




\section{List of figures and tables}

Figure 1. Conceptual analytical framework

Figure 2. The three successive ComMod cycles implemented between 2002 and 2005 in Mae Salaep village, Chiang Rai Province, northern Thailand

Figure 3. Initial power relations among the local participants in the ComMod process implemented in 2005 at Mae Salaep village,Chiang Rai Province, northern Thailand

Table 1. Characteristics of the main types of farming households in Mae Salaep, Chiang Rai Province, northern Thailand

Table 2. Participants' answers to the question "did the process allow you to learn something about other participants?” 